\title{
Evaluation of an Organic Nitrogen Source in a Yellow Squash-Collard Rotation
}

\author{
Charles Zachry Ogles ${ }^{1}$, Joseph M. Kemble, and Amy N. Wright \\ Department of Horticulture, 101 Funchess Hall, Auburn, AL 36849
}

\section{Elizabeth A. Guertal \\ Department of Crop, Soil and Environmental Sciences, 201 Funchess Hall, Auburn, AL 36849}

Additional index words. fertigation, fish fertilizer, Brassica oleracea var. acephala, Cucurbita pepo, economics, plasticulture, sulfur

\begin{abstract}
In-season nitrogen (N) management is a common challenge in organic vegetable production. This is especially true when using polyethylene mulch combined with fertigation. Soluble organic $N$ sources suitable for fertigation in organic vegetable production are needed. The objective of this research was to evaluate an organic fish fertilizer in a squash/collard rotation and to compare its effectiveness to inorganic sources. A 2-year crop sequence of yellow squash (Cucurbita pepo) and collards (Brassica oleracea var. acephala) was used. To eliminate the rotation order effect, the crops were switched each year: yellow squash-collard in Year 1 and collard-yellow squash in Year 2. Three $\mathbf{N}$ sources were used along with a zero $N$ control: hydrolyzed fish fertilizer (HFF), inorganic $\mathbf{N}$ source with secondary and micronutrients (INORGWM), and inorganic $\mathbf{N}$ without secondary or micronutrients (INORGWO). Three $N$ rates and a control were also included: 1) $\mathrm{N}$ at the recommended rate $\left(152 \mathrm{~kg} \cdot \mathrm{ha}^{-1}\right.$ for yellow squash and $110 \mathrm{~kg} \cdot \mathrm{ha}^{-1}$ for collards); 2) $\mathrm{N}$ at $80 \%$ of the recommended rate; 3 ) $\mathrm{N}$ at $60 \%$ of the recommended rate; and 4) a zero $N$ control. Year 2012 yellow squash had a $30 \%$ higher yield when grown with inorganic $N$ as compared with squash grown in HFF. Year 2012 collards had a $21 \%$ higher yield when grown with INORGWM as compared with collards grown in the HFF. In the second year, highest yields of collards were again produced in the INORGWM treatments followed by those grown in the HFF treatments. Second-year squash grown in the inorganic $\mathbf{N}$ treatments produced highest yields, and squash grown in the HFF had a $16 \%$ lower yield as compared with those grown in the two inorganic N sources. INORGWO produced lower marketable collard yields than INORGWM or HFF as a result of sulfur deficiency. Although yields were reduced in the crops grown in HFF treatments, the premium price and resultant profit associated with organic products were enough to offset the reduced yield. If growers can obtain the price premiums associated with organic produce, the use of HFF could be an economically feasible option in organic vegetable production.
\end{abstract}

Organic agriculture is one of the fastest growing segments of U.S. agriculture. In 2011, certified organic growers sold more than $\$ 3.5$ billion in organically grown agricultural commodities. Between 1992 and 2008 there has been a $361 \%$ increase in certified organic operations (Chapin, 2012). In 2010, the U.S. Department of Agriculture (USDA) reported a $7.7 \%$ increase in sales of organic products over those in 2009 (USDA, 2012), and this demand continues to grow (Beyond Pesticides, 2012). In response, there has been an increase in the number of organic growers needed to meet this demand.

In organic production, the use of inorganic fertilizer is largely prohibited. As a result, organic growers depend on the use of natural sources such as manures, legume

Received for publication 1 July 2014. Accepted for publication 26 Aug. 2014

${ }^{1}$ To whom reprint requests should be addressed; e-mailczo0005@auburn.edu. cover crops, animal byproducts, and naturally formed minerals. The pre-plant application of nutrients is an effective practice with a few exceptions, $\mathrm{N}$ and potassium $(\mathrm{K})$ being most notable. These two nutrients are required in relatively large quantities and often become limited as a plant grows and matures. As a result, it is recommended to apply a portion of the $\mathrm{N}$ and $\mathrm{K}$ pre-plant and the remainder be applied throughout the growing season (Kemble, 2012).

The management of in-season fertility can be a limiting factor in the production of high N-demanding crops (Hartz et al., 2010). This is particularly true when polyethylene mulch is used as the surface covering, restricting the ability to surface-apply supplemental fertilizer midseason. This issue is typically overcome by installing drip irrigation beneath the polyethylene mulch to provide water and nutrients. Previously, organic growers have relied on the use of sodium nitrate for this application. Sodium nitrate, however, is being considered for removal from the National Organic Program's list of allowable synthetic substance and its use banned in organic production (McEvoy, 2012). With the potential loss of sodium nitrate, an injectable organic $\mathrm{N}$ source that is allowable in organic production and proven effective is needed to fill this void. HFF has been used as a supplemental fertilizer in organic production for many years (Gaskell and Smith, 2007). Hydrolyzed fish fertilizer is produced through an enzymatic process where fish proteins are broken down into their base amino acids (S.F. Organics, 2013). Unfortunately, there has been limited research as to the effectiveness of such products; thus, research in this area is needed.

The cost per unit of available $\mathrm{N}$ has also been a concern as to the profitability of using HFF in organic production (Hartz and Johnstone, 2006). The issue of availability is directly related to $\mathrm{N}$ mineralization. Results of previous studies indicated that HFF had one of the fastest and most complete mineralization rates among all liquid organic fertilizers tested. After 2 weeks of incorporation and incubation at 10 to $25^{\circ} \mathrm{C}$, between $47 \%$ and $60 \%$ of the organic $\mathrm{N}$ had been mineralized (Hartz and Johnstone, 2006). Rapid mineralization rates not only supply the plant with quickly available $\mathrm{N}$, but also ensure that the grower receives the full financial and nutritive value of the products applied. Although organically grown products typically command a significant price premium of $60 \%$ or more over conventional products, production costs for organic growers are often a limiting factor (Lin et al., 2008). As a result, growers continually search for methods that will maximize profit while reducing overall cost.

The practice of double-cropping is common among vegetable growers who use polyethylene mulch (Rice et al., 2007). This practice reduces production cost by splitting the mulch costs over multiple crops. Growers who will double-crop typically select a crop that is planted immediately after the termination of the previous crop. Often, these are unrelated crops that will thrive under different seasons and that share few pests. This management system not only reduces overhead costs for growers, but it also keeps the land continuously producing a cash crop.

Thus, the objective of the research was to evaluate the use of HFF as a source of organic $\mathrm{N}$ along with inorganic $\mathrm{N}$ sources at various rates in a plasticulture rotation of yellow squash (Cucurbita pepo cv. Conqueror III) (Seminis Seed Co., St. Louis, MO) and collards (Brassica oleracea var. acephala cv. Blue Max) (Abbott and Cobb, Feasterville, PA).

\section{Materials and Methods}

Plant material and growth conditions. Field studies were conducted beginning on 6 July 2012 and continued until 26 Sept. 2013 at the Horticulture Unit of the E.V. Smith Research Center (Shorter, AL) on a Norfolk fine sandy loam (fine-loamy, siliceous thermic 
Typic Paledult). Research was conducted on conventionally managed plots in an effort to better control variables that would have certainly confounded the results of an $\mathrm{N}$ source evaluation. Disease, weed, and insect control were accomplished through the use of both conventional and organic pesticides. Soil samples were taken before the start of the experiment and analyzed to assess the initial nutrient content of the soil. Soil phosphorus $(\mathrm{P})$ and $\mathrm{K}$ were determined to be 33 and $66 \mathrm{ppm}$, respectively, and organic matter was $0.8 \%$. Based on this test, no supplemental $\mathrm{P}, \mathrm{K}$, or lime was required.

The experiment used a 2-year crop rotation scheme with summer squash and collards in the summer and fall of 2012, respectively. To eliminate the rotation order effect, the crops were switched in each year: yellow squash-collard in 2012 and collard-yellow squash in 2013. To maximize the cost-benefits of double-cropping, a total of four crops (two of each crop alternating in the 2 years) were grown using the same spacing, polyethylene mulch, and drip irrigation. The rotation sequence chosen for this experiment allowed the land to be kept in near constant production, increasing the income potential as well as allowing for the evaluation of the $\mathrm{N}$ source on soil $\mathrm{N}$ content over time. Yellow squash and collards were selected for this experiment to replicate a practical rotation that would thrive in the southeastern United States. Three $\mathrm{N}$ rates and a control were included: 1) $\mathrm{N}$ at the recommended rate

Table 1. Climate data for each of the four growing seasons as recorded by the on-site weather station located at E.V. Smith Research Unit in Shorter, AL.

\begin{tabular}{lccccc}
\hline & \multicolumn{2}{c}{ Yellow squash } & & \multicolumn{2}{c}{ Collards } \\
\cline { 2 - 3 } \cline { 5 - 6 } & 2012 & 2013 & & 2012 & 2013 \\
\hline Average air temperature $\left({ }^{\circ} \mathrm{C}\right)$ & 26.6 & 24.4 & & 12.8 & 15.5 \\
Average soil temperature $\left({ }^{\circ} \mathrm{C}\right.$ at $\left.10 \mathrm{~cm}\right)$ & 34.0 & 31.0 & & 18.8 & 19.1 \\
Evapotranspiration $(\mathrm{ET} \mathrm{mm} /$ day $)$ & 0.23 & 0.20 & & 0.13 & 0.14 \\
Rainfall total $(\mathrm{cm})$ & 20.1 & 15.1 & & 7.74 & 17.6 \\
Average day length (hours) & 13.52 & 12.73 & & 10.87 & 12.75 \\
\hline
\end{tabular}

(152 $\mathrm{kg} \cdot \mathrm{ha}^{-1}$ for yellow squash and 110 $\mathrm{kg} \cdot \mathrm{ha}^{-1}$ for collards); 2) $\mathrm{N}$ at $80 \%$ of the recommended rate; 3) $\mathrm{N}$ at $60 \%$ of the recommended rate; and 4) a zero $\mathrm{N}$ control. Conventionally produced and treated seed were selected to reduce disease issues, which would affect the evaluation of the $\mathrm{N}$ sources in the experiment. Planting dates for the squash were 6 July 2012 and 2 Aug. 2013 and 2 Oct. 2012 and 22 Mar. 2013 for the collards. Weather data were collected during each crop cycle to allow for comparison between years (Table 1). The first squash crop was direct-seeded, whereas the second squash crop and both collard crops were established as 4- and 6-week-old transplants, respectively, in plug trays with a $3.7-\mathrm{cm}$-sized cell. A total of 26 plants were grown in each of the 40 plots in single rows spaced $0.45 \mathrm{~m}$ apart. Plant spacing was the same for all four crops in both 2012 and 2013. Each of the plots consisted of a 12.2-m section of a raised, polyethylene mulch-covered bed.

The experiment was conducted in $0.15-\mathrm{m}$ raised beds spaced $1.8 \mathrm{~m}$ from center. Before the installation of the polyethylene mulch in 2012 , beds were pre-formed and $17.6 \%$ of the total recommended $\mathrm{N}\left(152 \mathrm{~kg} \cdot \mathrm{ha}^{-1} \mathrm{~N}\right)$ for the initial summer squash planting was applied pre-plant (Kemble, 2012). Thus, 26.9, 21.6, and $16.1 \mathrm{~kg} \cdot \mathrm{ha}^{-1} \mathrm{~N}$ were applied for the $100 \%, 80 \%$, and $60 \% \mathrm{~N}$ treatments, respectively. All pre-plant fertilizers were applied as an aqueous solution $0.15 \mathrm{~m}$ into the center of each bed into a $25 \mathrm{~mm} \times 25-\mathrm{mm}$ pre-formed furrow. Plots were fertilized with the type fertilizer specifically assigned to that plot at the initiation of the study. Each experimental plot was treated with the same $\mathrm{N}$ source, i.e., same treatment, throughout the 2 -year experiment, and no re-randomization of plots occurred.

White on black polyethylene mulch $(1.5 \mathrm{~m}$ wide $\times 0.05 \mathrm{~mm}$ thick; Berry Plastics Corp., Evansville, IN) was installed immediately after the pre-plant fertilizer was applied. The mulch was installed with drip irrigation (T-Tape; $0.25 \mathrm{~mm}$ wall thickness, $0.30-\mathrm{m}$ emitter spacing, San Marcos, CA). The delivery rate of irrigation tape was $5.59 \mathrm{~L}$ per $100 \mathrm{~m}$ per minute at a pressure range of 55 to $82 \mathrm{kPa}$. Irrigation was applied at a rate of 2.5 to $5 \mathrm{~cm}$ per week depending on the growth stage of the crop, temperature, rainfall, and evapotranspiration rates (Table 1) (Kemble, 2012).

The plots were regularly scouted to manage irrigation, insect, disease, and weed pressure. Insect, disease, and weed management were accomplished by following the guidelines set forth in the 2012 SE US Vegetable Crop Handbook (Kemble, 2012).

The experiment was arranged as a randomized complete block design consisting of 10 treatments with four replicates. Each of the 10 treatments was applied to one plot in each of the four blocks used in this experimental design. Fertilizer treatments were: 1) HFF (Schafer's Liquid Fish; Schafer Fisheries, Inc., Thomson, IL); 2) INORGWO; 3) INORGWM; and zero N control (Table 2). To balance all the nutrients to uniformity (with the exception of $\mathrm{N}$ ) across all treatments, the nutrient content of the HFF was used as a reference point, and nutrient content of the two inorganic treatments was adjusted accordingly (Table 2). The $\mathrm{N}$ content was balanced within source so that the same nitrate $\left(\mathrm{NO}_{3}\right)$ to ammonium $\left(\mathrm{NH}_{4}\right)$ ratio was supplied in all inorganic treatments (Camberato, $2001)$. The ratio was $57 \%\left(\mathrm{NO}_{3}\right)-\mathrm{N}$ and $43 \%$ $\left(\mathrm{NH}_{4}\right)-\mathrm{N}$.

Table 2. Nutrient content of hydrolyzed fish fertilizer (HFF) and nutrient sources used to balance nutrient contents to uniformity in the two inorganic treatments. ${ }^{z}$

\begin{tabular}{|c|c|c|c|c|c|c|}
\hline Nutrient & \multicolumn{2}{|c|}{$\begin{array}{l}\text { Hydrolyzed fish } \\
\text { fertilizer }(\mathrm{HFF})^{\mathrm{y}}\end{array}$} & \multicolumn{2}{|c|}{$\begin{array}{l}\text { Inorganic with secondary } \\
\text { and micronutrients (INORGWM) }\end{array}$} & \multicolumn{2}{|c|}{$\begin{array}{l}\text { Inorganic without secondary } \\
\text { and micro nutrients (INORGWO) }\end{array}$} \\
\hline $\mathrm{NH}_{4}-\mathrm{N}$ & $152 \mathrm{~kg}$ & $\mathrm{HFF}$ & $66 \mathrm{~kg}$ & $\left(\mathrm{NH}_{4}\right)_{2} \mathrm{SO}_{4}, \mathrm{CO}\left(\mathrm{NH}_{2}\right)_{2}$ & 66 & {$\left[\mathrm{NH}_{4} \mathrm{NO}_{3}, \mathrm{CO}\left(\mathrm{NH}_{2}\right)_{2}\right]$} \\
\hline $\mathrm{K}^{\mathrm{v}}$ & $126 \mathrm{~kg}$ & HFF & $126 \mathrm{~kg}$ & $\mathrm{~K}_{2} \mathrm{SO}_{4}$ & 126 & $\mathrm{KNO}_{3}$ \\
\hline $\mathrm{Ca}$ & $106 \mathrm{~kg}$ & HFF & $106 \mathrm{~kg}$ & $\mathrm{Ca}\left(\mathrm{NO}_{3}\right)_{2}$ & 0 & NA \\
\hline $\mathrm{Mg}$ & $2.35 \mathrm{~kg}$ & HFF & $2.35 \mathrm{~kg}$ & $\mathrm{MgSO}_{4}$ & 0 & NA \\
\hline $\mathrm{Fe}$ & $830 \mathrm{~g}$ & $\mathrm{HFF}$ & $830 \mathrm{~g}$ & Fe EDTA & 0 & NA \\
\hline $\mathrm{Zn}$ & $317 \mathrm{~g}$ & HFF & $317 \mathrm{~g}$ & $\mathrm{Zn}$ chelate & 0 & NA \\
\hline $\mathrm{Na}$ & $7.62 \mathrm{~kg}$ & $\mathrm{HFF}$ & $7.62 \mathrm{~kg}$ & $\mathrm{NaCl}, \mathrm{NaHCO}_{3}$ & 0 & NA \\
\hline $\mathrm{Cl}$ & $7.62 \mathrm{~kg}$ & $\mathrm{HFF}$ & $7.62 \mathrm{~kg}$ & $\mathrm{NaCl}$ & 0 & NA \\
\hline
\end{tabular}

${ }^{\mathrm{z}}$ Amounts shown are for the $100 \%$ of the recommended nitrogen $(\mathrm{N})$ treatment $(152 \mathrm{~kg} \mathrm{~N} / \mathrm{ha})$ for squash. Nutrient rates were adjusted accordingly for the $80 \%$ and $60 \%$ of the recommended $\mathrm{N}$ rate.

${ }^{y}$ Nutrients supplied when applied at the rate of $5227 \mathrm{~L} \cdot \mathrm{ha}^{-1}$

${ }^{\mathrm{x}}$ Not detected in laboratory analysis.

${ }^{w}$ Calculated as actual P.

${ }^{\mathrm{v}}$ Calculated as actual.

$\mathrm{P}=$ phosphorus $\mathrm{K}=$ potassium $; \mathrm{Ca}=$ calcium; $\mathrm{Mg}=$ magnesium $; \mathrm{S}=$ sulfur $; \mathrm{Mn}=$ manganese $; \mathrm{Fe}=$ iron; $\mathrm{Zn}=$ zinc $; \mathrm{Na}=$ sodium; $\mathrm{Cl}=$ chlorine $; \mathrm{NA}=$ not applicable. 
To accurately deliver each fertility treatment across the four replicates, an extensive network of polyethylene pipe (Toro Flex Pipe; 13 mm; Toro Co., Bloomington, MN) and a Dosatron D45RE (Dosatron Intl., Clearwater, FL) fertigation injector was used. Fertilizer treatments were injected twice weekly during each crop cycle with the inorganic treatments dissolved in $\approx 1 \mathrm{~L}$ of water and injected. The HFF was measured and added on site using a $2000 \mathrm{~mL}$ graduated cylinder. There were two instances where products were injected separately, and this was done to prevent chemical reactions from occurring. First was the separate injection of calcium nitrate, and the second was the separate injection of $\mathrm{K}_{2} \mathrm{CO}_{3}$ (as part of the HFF treatment). The combination of calcium and sulfur resulted in the formation of precipitants and the combination of the strongly acid $\mathrm{HFF}$ with $\mathrm{K}_{2} \mathrm{CO}_{3}$ produced gas bubbles making injection difficult. Treatment applications began with a 30 -min pre-wet cycle where the beds were wet with water to help improve fertilizer movement into the soil as well as to ensure the system was up to full operating pressure (55 to $82 \mathrm{kPa}$ ) before injection began. All treatments passed through 150-mesh filters before entering the drip system. Each fertilizer treatment took $\approx 30 \mathrm{~min}$ to completely inject and allow for sufficient time to flush the lines.

Foliar and soil analyses. Each week $\approx 12$ leaves from recently expanded and fully matured leaves were collected from each plot. Leaves were collected and placed into a convection drying oven at $75^{\circ} \mathrm{C}$ for $48 \mathrm{~h}$ or until at a constant weight. Leaves were then ground into a fine powder using a Cyclone Sample Mill (UDY Corporation, Fort Collins, $\mathrm{CO})$ in preparation for laboratory analysis. Total $\mathrm{N}$ content was determined through dry combustion techniques (Leco-CHN600, Leco Corporation, St. Joseph, MI) (Bremner and Mulvaney, 1986), and other tissue nutrient concentration $(\mathrm{P}, \mathrm{K}$, calcium, magnesium, sulfur, manganese, iron) was determined through dry combustion and analysis through inductively coupled argon plasma spectrometry.

Canopy height and canopy width data were collected weekly from five randomly selected plants in each plot. The canopy height was recorded from the soil line to the highest point on the plant. The canopy width was determined by measuring the widest point across the plant. Representative plants from each plot were selected to be measured.

Leaf chlorophyll measurements were taken weekly until harvest using the SPAD 502 Chlorophyll meter (SPAD 502; Minolta Co. Ltd., Japan). Five readings were taken from randomly selected plants with recently expanded, mature leaves in each plot and recorded. The area to the right of each midrib was tested to reduce sampling variation.

Soil samples were collected from each plot after each crop was ended. Soil tests were performed to determine if significant differences existed in $\mathrm{N}$ accumulation based on $\mathrm{N}$ source and $\mathrm{N}$ rate. Four soil samples were taken from the center of each bed to a depth of $15 \mathrm{~cm}$ using a handheld cylindrical soil probe. Soil NH4-N and $\mathrm{NO}_{3}-\mathrm{N}$ content was determined through microtiter plate colorimetric analysis (Sims et al., 1995). In addition to $\mathrm{N}$ analysis, the soil samples were analyzed to ensure that $\mathrm{pH}$ ranges remained similar among $\mathrm{N}$ sources and rates.

Yield data collection. For squash, each plot was harvested three times per week for a period of 3 to 4 weeks. Total weight and total fruit number of US \#1 fruit were determined. Cull weight and cull number of each plot were determined for each plot. All grading was done according to the USDA standards for fresh-market summer squash (USDA, 1984). Collards were harvested on 12 Dec. 2012 and 17 May 2013. Weight of each harvested plant was recorded and the total number of harvested plants per plot recorded. Bunches were size-separated into US \#1 and cull, and the number of each was recorded. Grading was done according to the USDA guidelines for collard or broccoli greens (USDA, 1953).

Statistical analysis. All data were subjected to analysis of variance and regression procedures (PROC CORR, PROC MIXED, and PROC REG) (SAS Institute, Cary, NC). All data from each crop were combined over years and analyzed together. In cases in which interactions occurred between a specific crop and year, data were reanalyzed by year.

Economic analysis. Enterprise budgets were developed for the treatments in this study using cost information from the 2013 Mississippi State Budget Generator 6.0 (Starkville, MS) as well as a budgeting program developed by The University of Florida (Hewitt, 2003) for use in Excel (Microsoft Inc., Redmond, WA). Variable costs were based on the actual inputs used in each of the treatments including such items as seed, fertilizers, plastic mulch, drip tape, pesticides, irrigation, and specialized labor associated with the application of these items. Available budgets were based on a single-season use of plastic mulch and drip tape; however, the rotation in this experiment allowed for this cost to be spread across four crops. Because of this, the cost associated with the installation of plastic mulch was added to the budget of the first crop in the rotation. Similarly, the cost associated with the clean-up and removal of mulch was included in the budget of the final crop in the rotation.

Harvest and marketing costs were determined by calculating labor costs to harvest, sort, grade, and package based on the yield produced from each treatment on a per-hectare basis. Costs varied based on the yield produced in each treatment. As yield increased, additional costs were generated as a result of the extra labor to harvest and more containers needed to market the harvested crops. On the other hand, as yield decreased, so did harvest costs. Fixed costs such as management, machinery, and irrigation systems were calculated based on approximate costs per hectare as provided in a budgetgenerating program (Hewitt, 2003).
The return on investment was based on the USDA terminal market price for collards and the USDA retail price for summer squash. The premium price for organically produced products was determined by USDA sales records from the specific date each crop was harvested and would have entered the market (USDA, 2013).

\section{Results and Discussion}

\section{Leaf nitrogen}

Summer squash. Summer squash leaf N concentration was affected by $\mathrm{N}$ source throughout the 2012 and 2013 seasons, whereas the main effect of $\mathrm{N}$ source and $\mathrm{N}$ rate did not interact at any sampling date (Table 3). Nitrogen rate affected summer squash leaf $\mathrm{N}$ content only at one sampling date (31 July 2012) in 2 years. At this date, leaf $\mathrm{N}$ concentration increased as $\mathrm{N}$ rate increased.

When the main effect of $\mathrm{N}$ source was significant, it was because leaf $\mathrm{N}$ concentration was higher in summer squash grown in the INORGWO as compared with summer squash receiving INORGWM (Fig. 1). Nitrogen source treatments with secondary and micronutrients, HFF, and the inorganic with minors INORGWM had no significant differences in leaf $\mathrm{N}$ content throughout the 2012 season.

In 2012, leaf $\mathrm{N}$ concentrations were found to be within the established sufficiency range of $4.0 \%$ to $6.0 \% \mathrm{~N}$ for summer squash (Mills and Jones, 1996). Samples taken on 31 July 2012 at the early bloom stage of crop development indicate that adequate $\mathrm{N}$ was available for plant uptake (Fig. 1). Residual $\mathrm{N}$ supplied by the previous ryegrass cover crop, which was tilled under just before the start of the experiment, likely diminished the effects of $\mathrm{N}$ rate on the first crop in the sequence.

In 2013, when the main effect of $\mathrm{N}$ source was significant, it was because leaf $\mathrm{N}$ concentration was higher in summer squash grown in the inorganic treatments INORGWO as compared with summer squash receiving INORGWM or HFF (Fig. 1). The increased $\mathrm{N}$ content found in leaves from the INORGWO treatment was determined to be the result of a sulfur (S) deficiency (Tabatabai, 1986).

In 2013, N source significantly affected summer squash leaf $\mathrm{N}$ concentration at every sampling date (Table 3). Like in 2012, no differences were detected in leaf $\mathrm{N}$ concentration between the HFF and the INORGWM treatments. Leaf $\mathrm{N}$ concentration in the summer squash treatments that received INORGWO had higher leaf $\mathrm{N}$ concentration, presumably from the $\mathrm{S}$ deprivation mentioned previously (Fig. 1). Although leaf $\mathrm{N}$ concentrations were highest in the INORGWO treatments, plant canopy area was largest in the plots receiving the INORGWM and the HFF treatments at the $100 \% \mathrm{~N}$ rate $(P<0.001)$

Collards. Leaf $\mathrm{N}$ concentration of collards was affected by an interaction between $\mathrm{N}$ source and $\mathrm{N}$ rate on one sampling date in 2012 and once again in 2013 (Table 3). In 
Table 3. Analysis of variance table of the effect of nitrogen $(\mathrm{N})$ source, $\mathrm{N}$ rate, and their interaction on leaf $\mathrm{N}$ of summer squash and collards, Horticulture Unit, Tallassee, AL, 2012 and 2013.

\begin{tabular}{|c|c|c|c|c|c|c|c|c|c|c|c|}
\hline & \multicolumn{11}{|c|}{ Leaf $\mathrm{N}$ content summer squash } \\
\hline & \multicolumn{6}{|c|}{ - } & \multicolumn{5}{|c|}{ - } \\
\hline N source & $\mathrm{NS}^{\mathrm{z}}$ & 0.006 & 0.0004 & NS & & & 0.001 & 0.0002 & 0.0004 & 0.002 & 0.002 \\
\hline \multirow[t]{3}{*}{$\mathrm{N}$ source $\times \mathrm{N}$ rate } & NS & NS & NS & NS & & & NS & NS & NS & NS & NS \\
\hline & -------- & - & - & Collards 2012 -- & 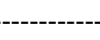 & ----------- & ------------ & -------- & ---- Colla & ls $2013---$ & ---------- \\
\hline & 23 Oct. & 30 Oct. & 6 Nov. & 13 Nov. & 20 Nov. & 27 Nov. & 8 Dec. & 25 Apr. & 2 May & 9 May & 14 May \\
\hline $\mathrm{N}$ source $\times \mathrm{N}$ rate & NS & NS & NS & 0.03 & NS & NS & NS & NS & NS & NS & 0.02 \\
\hline
\end{tabular}

${ }^{\mathrm{z}}$ Nonsignificant.
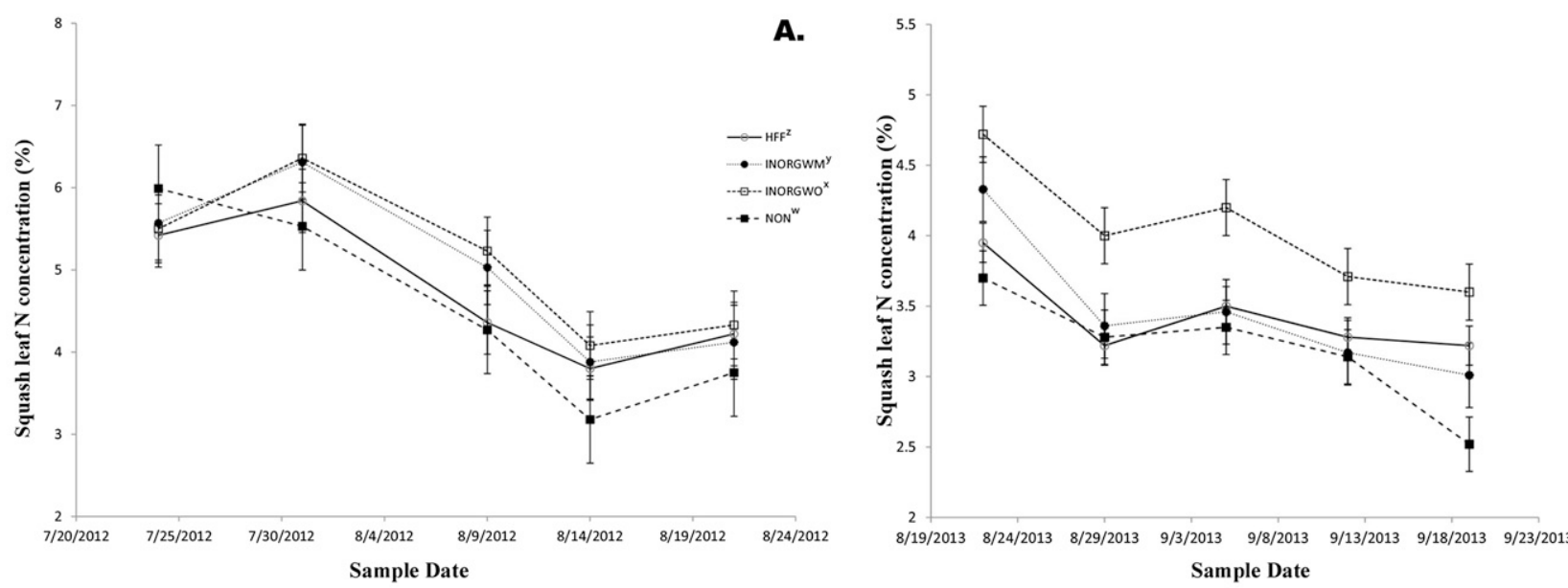

B.
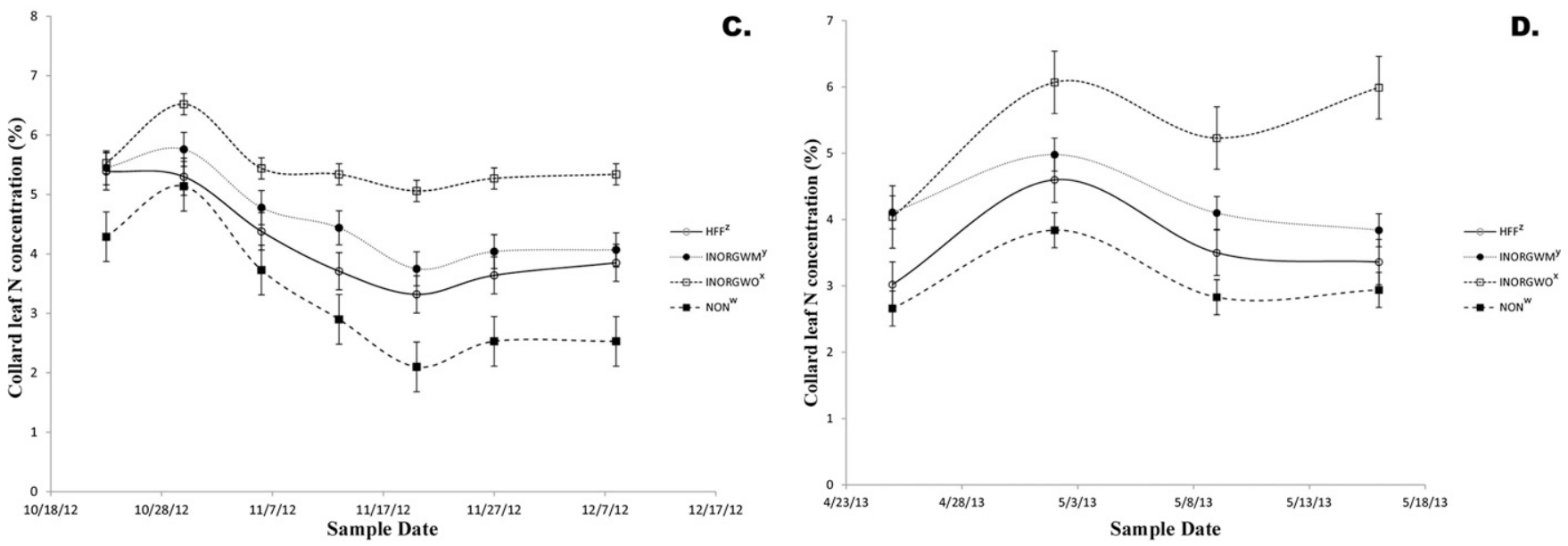

Fig. 1. Leaf nitrogen concentration as affected by nitrogen (N) source and sample date for squash and collards in 2012 and 2013. (A) Squash 2012. (B) Squash 2013. (C) Collard 2012. (D) Collard 2013. Each marker represents the mean N concentration on each given date. Vertical lines are sE, Horticulture Unit, Tallassee, AL, 2012-13.

2012, the six treatments receiving secondary and micronutrients HFF and INORGWM at $100 \%, 80 \%$, and $60 \%$ of the recommended $\mathrm{N}$ rate had similar leaf $\mathrm{N}$ concentration over the dates sampled averaging $4.1 \% \mathrm{~N}$. Collards receiving the $100 \%$ rate of $\mathrm{HFF}$, INORGWM, and INORGWO had average leaf $\mathrm{N}$ content of $4.10 \%, 4.26 \%$, and $5.44 \%$ $\mathrm{N}$, respectively (Fig. 1). All treatments receiving the $100 \% \mathrm{~N}$ rate regardless of source were within the recommended $\mathrm{N}$ sufficiency range of $4.00 \%$ to $5.00 \% \mathrm{~N}$ at the midpoint of the crop (6 Nov. 2012) (Mills and Jones,
1996). Collard canopy area was affected by $\mathrm{N}$ rate and source on two sampling dates (20 and 27 Nov.). On both dates, the plots receiving the highest $\mathrm{N}$ rates of INORGWM and HFF had the largest canopy area. Collards from the zero $\mathrm{N}$ control had an average leaf $\mathrm{N}$ concentration of $2.53 \% \mathrm{~N}$. Among N sources, collards receiving the INORGWO treatments had consistently higher leaf $\mathrm{N}$ than collards receiving HFF, INORGWM, and the zero $\mathrm{N}$ control treatments (Fig. 1).

In 2013, similar results were found for the effect of $\mathrm{N}$ source on leaf $\mathrm{N}$ concentration
(Table 3). The lowest leaf $\mathrm{N}$ content was in the zero $\mathrm{N}$ control, and the highest was again in the treatments receiving INORGWO (Fig. 1). On the last sampling date of 14 May, the plots receiving the $100 \%$ rate of $\mathrm{HFF}$, INORGWM, and INORGWO had average leaf $\mathrm{N}$ concentration of $3.63 \%, 4.05 \%$, and $5.49 \% \mathrm{~N}$, respectively. Unlike 2012, the collards receiving the HFF treatments had leaf $\mathrm{N}$ content below the recommended range regardless of $\mathrm{N}$ rate. Collards grown with zero $\mathrm{N}$ again had a low leaf $\mathrm{N}$ content of $2.94 \%$ N. Like with the 2012 collard crop, 
the plots receiving the highest $\mathrm{N}$ rates of INORGWM and HFF had the largest canopy area.

\section{Leaf chlorophyll}

Summer squash. In general, in 2012, N source, $\mathrm{N}$ rate, or their interactions rarely affected chlorophyll readings in the summer squash (Table 4). Residual nutrients present in the soil likely played a role in negating the effect of $\mathrm{N}$ source and $\mathrm{N}$ rate on the first crop in the rotation. The average SPAD reading for all $\mathrm{N}$ sources, excluding the control, was 34.3. In the control, plants receiving zero $\mathrm{N}$ had an average SPAD reading of 32.8 .

In 2013, there were differences in chlorophyll content in summer squash leaves resulting from $\mathrm{N}$ source, $\mathrm{N}$ rate, and their interaction on 30 Aug., 6 Sept., and 13 Sept. (Table 4). Average SPAD readings for the HFF, INORGWM, and INORGWO treatments were $37.0,40.1$, and 36.5 , respectively, at the full $100 \% \mathrm{~N}$ rate. When an interaction was significant, it was because the INORGWO treatment at the $80 \% \mathrm{~N}$ rate produced lower chlorophyll readings than found in other treatments. The effects of $\mathrm{S}$ deprivation in the $80 \% \mathrm{~N}$ rate treatments were more pronounced than in the lower $60 \% \mathrm{~N}$ rate or the higher $100 \% \mathrm{~N}$ rate. The reason for this large discrepancy is unknown.

Collards. At three dates during the 2012 collard crop, a significant interaction between $\mathrm{N}$ source and $\mathrm{N}$ rate occurred (Table 4). In 2012, SPAD readings increased as $\mathrm{N}$ rate increased. In 2013, SPAD readings increased quadratically as $\mathrm{N}$ rate increased and was maximized at a $\mathrm{N}$ rate of 175 $\mathrm{kg} \cdot \mathrm{ha}^{-1}$. During both years, SPAD readings were similar among $\mathrm{N}$ sources. Chlorophyll meter readings were always lowest in the control (Fig. 2).
In 2012 and 2013, a significant correlation between SPAD reading and leaf $\mathrm{N}$ concentration occurred near the midpoint of the crop cycle (Table 5). In general correlations were either not significant (in seven of 11 sampling dates) or weakly significant $\left(R^{2}\right.$ values 0.31 to 0.60$)$. If significant, correlations were found at 35 to $49 \mathrm{~d}$ after transplanting, the midcycle of crop development (Table 5). Correlation data presented here possibly support the use of SPAD meter readings as a potential method for determining leaf $\mathrm{N}$ concentration, but only at specific times during crop development.

\section{Soil analysis}

Soil $\mathrm{pH}$ data were unaffected by $\mathrm{N}$ source $(P=0.548)$ or $\mathrm{N}$ rate $(P=0.214)$, and there was no interaction between the two ( $P=$ 0.897). This is an important finding because $\mathrm{pH}$ can have a significant effect on the

Table 4. Analysis of variance table of chlorophyll readings (SPAD) as effected by nitrogen $(\mathrm{N})$ source and N rate on summer squash and collard.

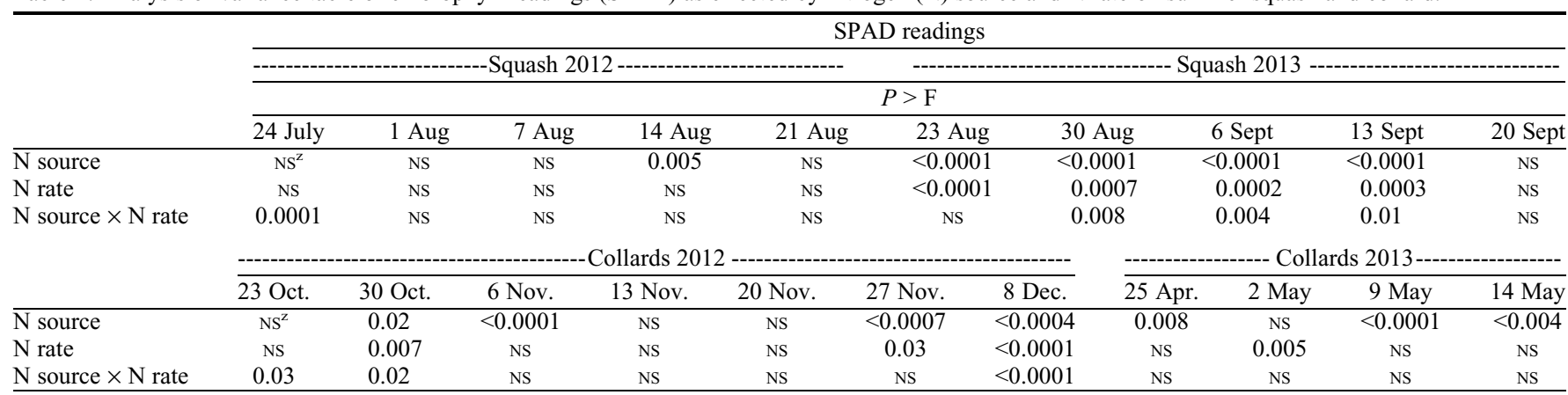

${ }^{\mathrm{z}}$ Nonsignificant.

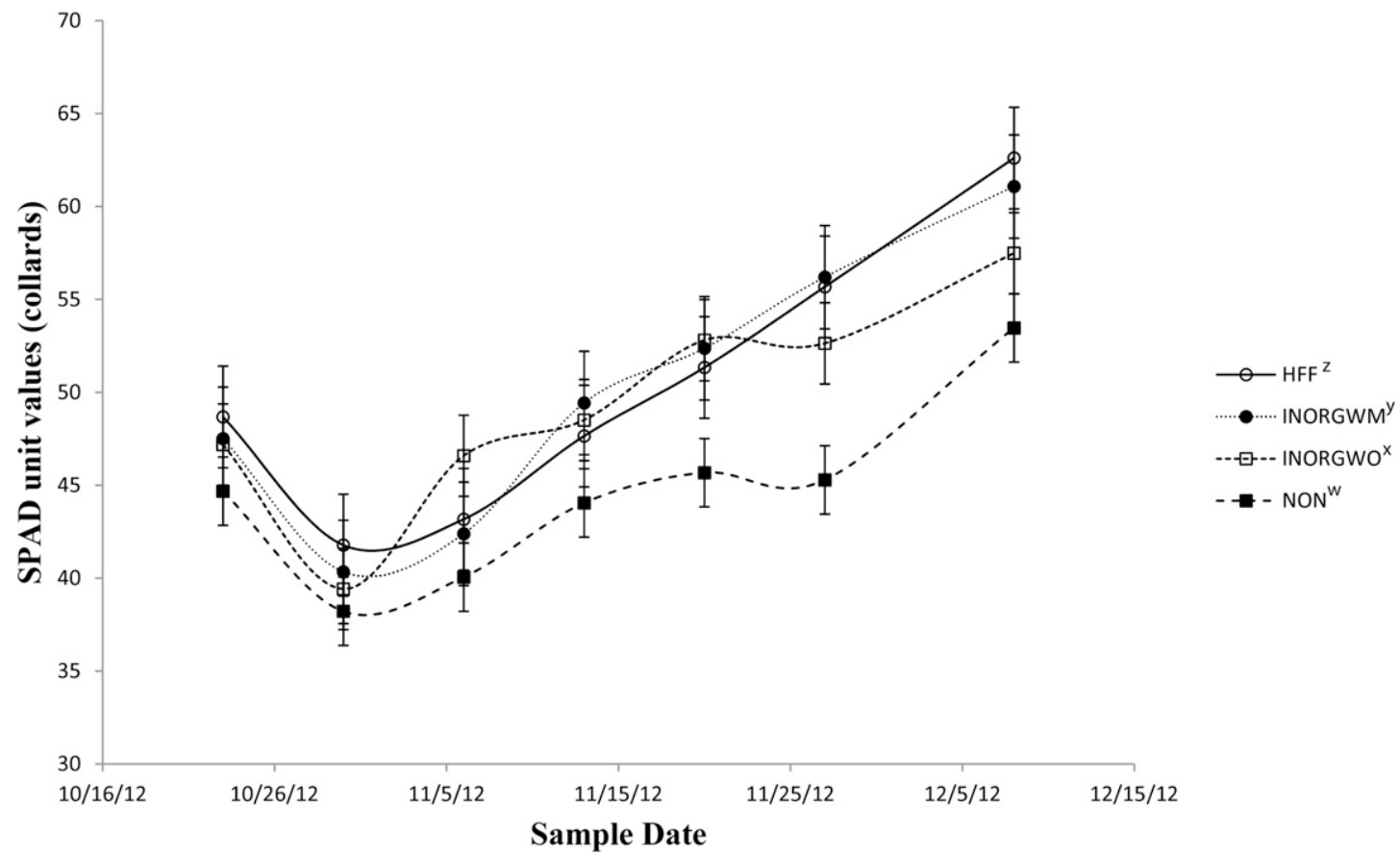

Fig. 2. Chlorophyll readings as measured by a SPAD meter as affected by nitrogen (N) source and sampling date collards, 2012. Vertical lines on each marker are the SE, Horticulture Unit, Tallassee, AL, 2012. 
availability of nutrients in the soil (Jones, 1998). Average $\mathrm{pH}$ readings from samples collected at the end of the experiment from plots receiving the $100 \% \mathrm{~N}$ rate of $\mathrm{HFF}$, INORGWM, INORGWO, and zero N control (NON) were 6.5, 6.4, 6.7, and 6.9, respectively.

There were no significant differences in total soil $\mathrm{N}, \mathrm{NH}_{4}-\mathrm{N}$, and $\mathrm{NO}_{3}-\mathrm{N}$ as affected by treatment. This was true at each sampling date as well as over the course of the entire study. This finding suggests that neither organic nor inorganic $\mathrm{N}$ accumulated differently as a result of $\mathrm{N}$ source during this 2-year period. This finding could be the result of the highly variable and dynamic nature of inorganic $\mathrm{N}$ in the soil.

\section{Yield}

Summer squash. In 2012, marketable yield of summer squash (USDA, 1984) was only affected by $\mathrm{N}$ source (Fig. 3). Increasing $\mathrm{N}$ rates above the $60 \% \mathrm{~N}$ rate had no effect on overall yield for both inorganic $\mathrm{N}$ sources.

Table 5. Pearson correlation coefficients between leaf nitrogen $(\mathrm{N})(\mathrm{Y})$ and $\operatorname{SPAD}(\mathrm{X})$ readings, by sample date, 2012 and 2013 collard crop.

\begin{tabular}{lccrc}
\hline Sample date & Days after transplanting & Regression equation & $R^{2}$ & $P$ value \\
\hline 23 Oct. 2012 & & 2012 & & \\
30 Oct. 2012 & 21 & $\mathrm{Y}=0.65 \mathrm{x}+43.9$ & 0.17 & $\mathrm{Ns}^{\mathrm{z}}$ \\
6 Nov. 2012 & 28 & $\mathrm{Y}=-0.16 \mathrm{x}+41.2$ & -0.05 & $\mathrm{NS}$ \\
13 Nov. 2012 & 35 & $\mathrm{Y}=2.26 \mathrm{x}+32.8$ & 0.60 & $<0.0001$ \\
20 Nov. 2012 & 42 & $\mathrm{Y}=1.11 \mathrm{x}+43.2$ & 0.31 & 0.0471 \\
27 Nov. 2012 & 49 & $\mathrm{Y}=1.35 \mathrm{x}+46.4$ & 0.40 & 0.0113 \\
8 Dec. 2012 & 56 & $\mathrm{Y}=0.62 \mathrm{x}+51.3$ & 0.14 & $\mathrm{NS}$ \\
& 63 & $\mathrm{Y}=-0.86 \mathrm{x}+63.3$ & -0.11 & $\mathrm{NS}$ \\
25 Apr. 2013 & & & & \\
2 May 2013 & 31 & $\mathrm{Y}=0.57 \mathrm{x}+43.7$ & 0.17 & $\mathrm{NS}$ \\
9 May 2013 & 38 & $\mathrm{Y}=0.93 \mathrm{x}+43.2$ & 0.18 & $\mathrm{NS}$ \\
16 May 2013 & 45 & $\mathrm{Y}=2.35 \mathrm{x}+33.9$ & 0.55 & 0.0003 \\
\hline
\end{tabular}

${ }^{\mathrm{z}}$ Nonsignificant.

Higher $\mathrm{N}$ rates did result in increased yields in plots receiving HFF. Marketable yield was highest in the INORGWM $\left(9488 \mathrm{~kg} \cdot \mathrm{ha}^{-1}\right)$ and INORGWO $\left(9157 \mathrm{~kg} \cdot \mathrm{ha}^{-1}\right)$ treatments. Summer squash grown in the HFF treatment had $24 \%$ lower marketable yield $\left(7137 \mathrm{~kg} \cdot \mathrm{ha}^{-1}\right)$ than that in the INORGWM treatment and $22 \%$ greater marketable yield than that in the unfertilized control (4868 kg.ha $\left.{ }^{-1}\right)$.

In 2013, highest marketable yield of summer squash was harvested from treatments receiving the highest recommended $100 \% \mathrm{~N}$ rate regardless of $\mathrm{N}$ source (Fig. 3). Highest marketable yield (3634 kg.ha ${ }^{-1}$ ) was obtained from the INORGWO treatment at the $100 \% \mathrm{~N}$ rate. Summer squash receiving the same rate of $\mathrm{N}$ as INORGWM had a $15.5 \%$ reduction, a yield of $3071 \mathrm{~kg} \cdot \mathrm{ha}^{-1}$. Yield of summer squash grown in the HFF treatments was significantly lower than that observed in either inorganic $\mathrm{N}$ treatment, and this was observed at all three $\mathrm{N}$ rates. Average yield of summer squash grown at the highest $\mathrm{N}$ rate in the INORGWO treatments was $3634 \mathrm{~kg} \cdot \mathrm{ha}^{-1}$ as compared with the highest $\mathrm{N}$ rate of $\mathrm{HFF}$, which was 2310 $\mathrm{kg} \cdot \mathrm{ha}^{-1}$, a reduction of $36 \%$ (Fig. 3). The lowest yielding treatment was the NON, which only produced $182 \mathrm{~kg} \cdot \mathrm{ha}^{-1}, 5 \%$ of the yield found in the highest yielding treatment.
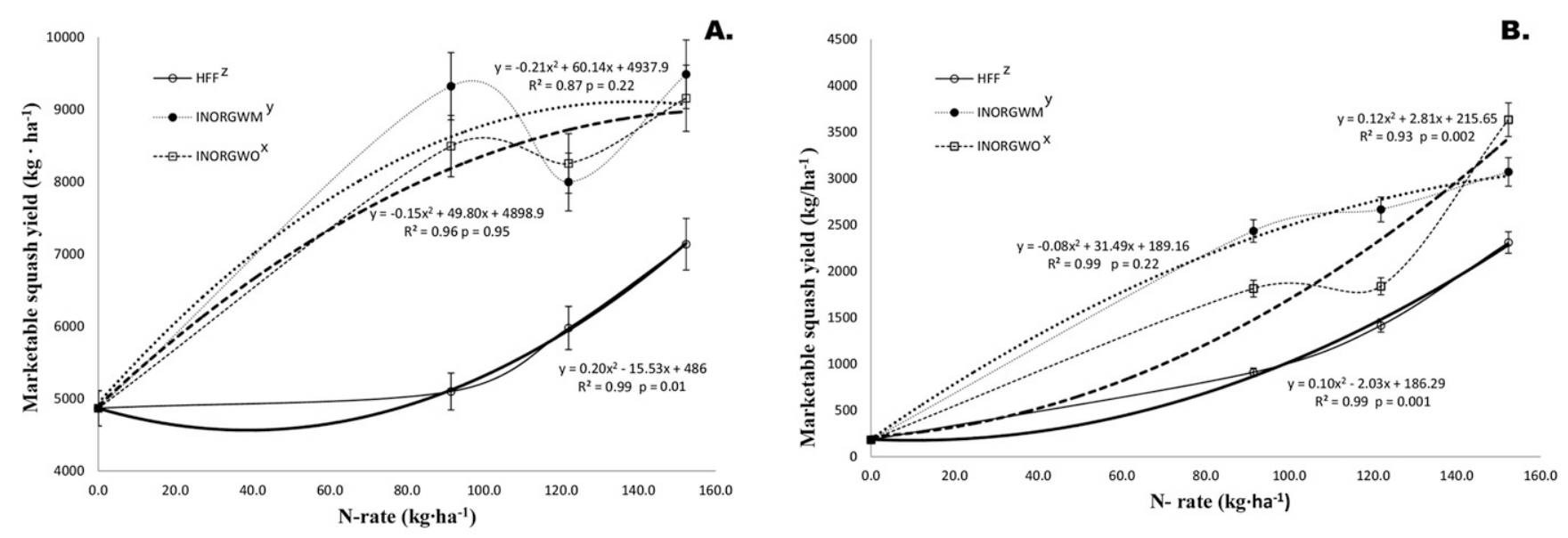

c.

D.
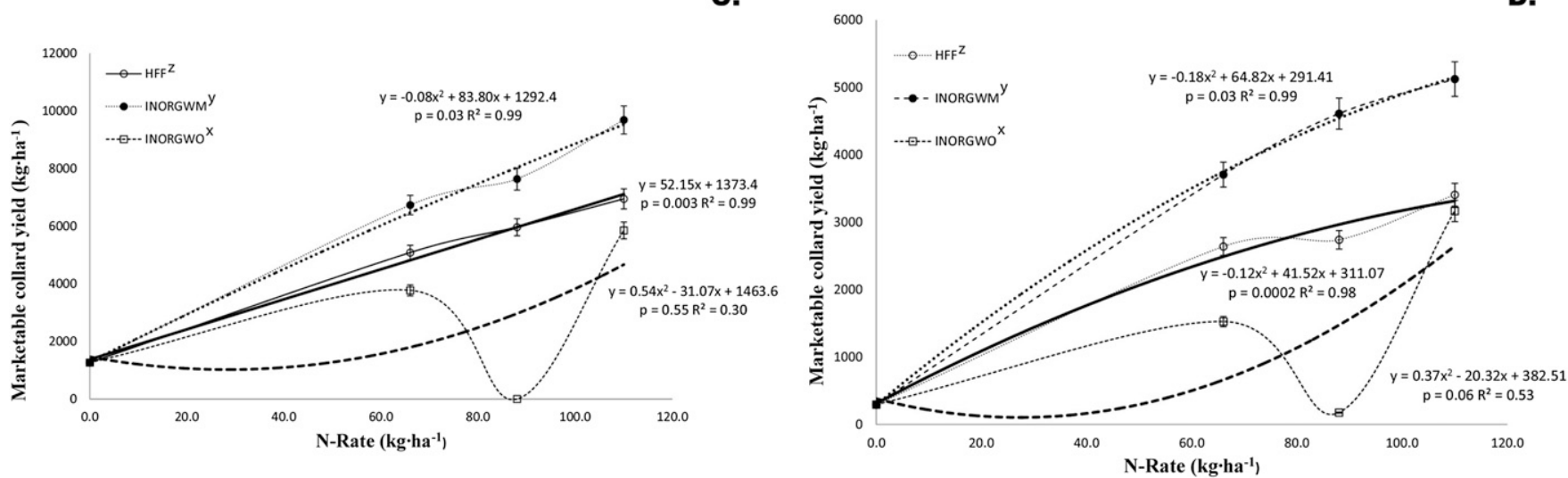

Fig. 3. Marketable yield of summer squash as affected by nitrogen $(\mathrm{N})$ rate and N source for squash and collard in 2012 and 2013. (A) Squash 2012. (B) Squash 2013. (C) Collard 2012. (D) Collard 2013. Vertical lines on each marker are the sE. Polynomial trend lines are shown for each N source, Hydrolyzed fish fertilizer (HFF), inorganic with secondary and micronutrients (INORGWM), and inorganic without secondary and micronutrients (INORGWO), Horticulture Unit, Tallassee, AL, 2012. 
Overall, 2013 summer squash yields were lower than those measured in 2012. The year in which the crops were produced along with the $\mathrm{N}$ source and $\mathrm{N}$ rate used proved to be significant factors in the analysis (Table 6). The highest yielding treatments from the 2013 crop were $60 \%$ lower in yield when compared with the highest yielding treatment in 2012. It is possible that this reduction in yield was caused in part by lower nutrient reserves in the soil resulting from the intensive rotation and further compounded by the high level of soil compaction that was prevalent across all plots. At the end of the final crop, it was clear that the beds had settled significantly since installation in 2012. In addition, the surface of the beds had become very firm when pressed. The similar summer squash yields found in the INORGWM and INORGWO treatments suggest that summer squash may be less sensitive to $\mathrm{S}$ deprivation and that secondary nutrients may play a less crucial role in their production. The reduced demand for $\mathrm{S}$ could be the result of lower levels of glucosinolates produced by cucurbits in comparison with Brassica crops (He, 1999). An alternative hypothesis is that differential rooting depths of the two crops could have played a role in $\mathrm{S}$ uptake. This could also be a function of increased soil temperature, which could increase soil $\mathrm{S}$ through mineralization during warm summer months in which the summer squash was grown as compared with the cooler fall months in which collards were grown (Warncke, 2007).

Collards. In both years, marketable yield of collards was significantly affected by an interaction between $\mathrm{N}$ source and $\mathrm{N}$ rate (Table 6). In general, marketable yield increased with increasing $\mathrm{N}$ rates. However, the interaction existed because collards grown in the INORGWM and HFF treatments had a similar response to increasing $\mathrm{N}$, whereas collards grown in the INORGWO treatment had a significant drop in yield at the $80 \% \mathrm{~N}$ rate, which was not observed at any other $\mathrm{N}$ rates.

Table 6. Summary of analysis of variance showing the sources of effects on total summer squash and collard yields for 2012 and 2013 .

\begin{tabular}{|c|c|c|c|c|c|c|}
\hline \multicolumn{4}{|c|}{ Summer squash yield } & \multicolumn{3}{|c|}{ Collard yield } \\
\hline Source of variation & $\mathrm{df}$ & $F$ value & $P$ value & $\overline{\mathrm{df}}$ & F Value & $P$ value \\
\hline $\mathrm{N}$ source & 2 & 16.7 & $<0.0001$ & 2 & 235.3 & $<0.0001$ \\
\hline $\mathrm{N}$ rate & 2 & 6.3 & $<0.0001$ & 2 & 86.2 & $<0.0001$ \\
\hline $\mathrm{N}$ source $\times \mathrm{N}$ rate & 4 & 0.7 & $\mathrm{NS}^{\mathrm{z}}$ & 4 & 27.1 & $<0.0001$ \\
\hline Year & 1 & 453.1 & $<0.0001$ & 1 & 358.3 & $<0.0001$ \\
\hline
\end{tabular}

${ }^{\mathrm{z} \text { Nonsignificant. }}$

$\mathrm{N}=$ nitrogen.

In 2012, yield in the INORGWO treatment was affected by a high number of culls (Fig. 3). For example, collards grown at the reduced $80 \% \mathrm{~N}$ rate had no marketable yield as a result of visual defects and unmarketable size. The most prominent symptoms were upwardly curled, thickened leaves, reddish coloration, stunted growth, and extremely high petiole $\mathrm{NO}_{3}$ concentrations. The symptoms were isolated to the inorganic without secondary and minor nutrients (INORGWO) treatments at $60 \%, 80 \%$, and $100 \%$ of the recommended $\mathrm{N}$ rates with particularly severe symptoms at the $80 \% \mathrm{~N}$ rate. Because a nutrient deficiency was suspected, an additional leaf tissue analysis was conducted to determine the total S content of four of these samples. The samples were taken from two of the most severely affected plots and from two adjacent unaffected plots for comparison. All four plots received the same rate of $\mathrm{N}$ with the only difference being the supply of secondary and micronutrients. The results of the analysis confirmed that a S deficiency was present. The average leaf $\mathrm{S}$ for the INORGWO was $0.24 \%$ as compared with the collards receiving HFF, which averaged $1.10 \% \mathrm{~S}(P=0.0035)$. The collards not receiving secondary and micronutrients were below the recommended value of $0.30 \%$ to $0.75 \% \mathrm{~S}$ for most crops in the Brassica oleracea family (Mills and Jones, 1996). The reason the collards grown with the $80 \%$ $\mathrm{N}$ rate were most severely affected is not clear. Yield was significantly reduced at all $\mathrm{N}$ rates in the INORGWO treatments as compared with yield from the INORGWM and the HFF treatment. As a result of a high number of visually unappealing cull plants, collards grown in the INORGWO treatments produced $65 \%$ and $18 \%$ less yield than from the highest $\mathrm{N}$ rate in the INORGWM and HFF treatments, respectively.

Results for 2013 collard yield were very similar to those measured in 2012 (Fig. 3). Again, collards receiving the highest $100 \% \mathrm{~N}$ rate yielded the highest number of marketable

Table 7. Economic analysis for the $100 \%$ nitrogen $(\mathrm{N})$ rate treatments in all four crops in the rotation.

Table 7. Economic analysis for the $100 \%$ Profit or loss per ha

\begin{tabular}{|c|c|c|c|c|c|}
\hline & & & Profit or lo & & \\
\hline & Summer squash & Collards & Collards & Summer squash & \\
\hline $\mathrm{N}$ source & 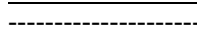 & ------------- & 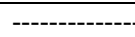 & 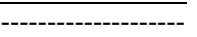 & Profit/loss 2012-13 \\
\hline $\mathrm{HFF}^{\mathrm{z}}$ & $13,638.15$ & $12,253.08$ & $-1,501.76$ & $-3,343.07$ & $21,046.40$ \\
\hline INORGWM $^{\mathrm{y}}$ & $13,962.84$ & $-1,758.37$ & $-3,935.80$ & $-2,008.95$ & $6,259.72$ \\
\hline INORGWO $^{\mathrm{x}}$ & $13,410.69$ & $-3,517.95$ & $-4,979.08$ & -347.97 & $4,913.67$ \\
\hline
\end{tabular}

${ }^{\mathrm{z}} \mathrm{HFF}=$ hydrolyzed fish fertilizer.

y INORGWM = inorganic N source with secondary and micronutrients.

${ }^{\mathrm{x}} \mathrm{INORGWO}=$ inorganic $\mathrm{N}$ source without secondary or micronutrients.

plants. In both the INORGWM and HFF treatments, collard yield increased with increasing $\mathrm{N}$ rate. Collards harvested from the INORGWO treatment again had a high number of culls.

In 2013, an overall reduction in yield was noted in comparison with the 2012 collard crop. This was true in all treatments regardless of $\mathrm{N}$ source or $\mathrm{N}$ rate. A yield reduction of $47 \%$ and $51 \%$ was observed in collards harvested from the INORGWM and HFF at the $100 \% \mathrm{~N}$ rate as compared with the 2012 collard crop. Yield of collard from the INORGWO treatments was also reduced from the previous year with a reduction of $45 \%$ observed at the highest $\mathrm{N}$ rate when compared with the 2012 crop. Reduced yields could best be attributed to the time of year in which the second collard crop was grown. In Alabama, collards produced in the fall are more common than those grown in the spring. Although the weather conditions, soil temperature, and evapotranspiration rates were comparable during the 2 years, spring temperatures are generally less predictable and can often exceed the optimal temperature for the crop.

\section{Economic analysis}

Summer squash 2012. Summer squash receiving the highest $\mathrm{N}$ rate always had the highest yield regardless of $\mathrm{N}$ source. Lowest yields were found in the zero $\mathrm{N}$ control plots. In this case the highest yielding treatment was the INORGWM, and it was the most profitable at $\$ 13,962 /$ ha followed closely by HFF at $\$ 13,638 /$ ha and last INORGWO at $\$ 13,410 /$ ha (Table 7). Although the HFF treatments yielded $32 \%$ less than the highest yielding treatment and had 121\% higher fertilizer costs, the $\$ 1.17 / \mathrm{kg}$ price premium for organically produced summer squash was nearly high enough to offset both.

Collards Fall 2012. Highest collard yields were harvested from the treatments receiving the highest $\mathrm{N}$ rate regardless of $\mathrm{N}$ source (Table 7). The lowest yield was found in the zero $\mathrm{N}$ control plots. The most profitable treatment was fertilized with HFF. This was because the plots receiving the HFF treatment produced good yields combined with the higher price obtained for organically produced collards. The higher profit obtained for the collards grown in the HFF treatment was the result of the $262 \%$ higher market price for organically produced collards. This price differential was more than enough to offset the additional fertilizer costs and reduced yield measured in the HFF treatment. 
Collards harvested from the HFF treatment had a profit of $\$ 12,253 /$ ha, whereas the next closest treatment, INORGWM, had a net loss of $\$ 1,758 /$ ha followed by the lowest yielding and the least profitable of the treatments: INORGWO. Reduced collard yields found in the INORGWO treatment were the result of poor yield and unmarketable plants. The INORGWO treatment had a net loss of $\$ 3517 /$ ha. Like with the 2012 summer squash crop, highest yields and profits came from treatments receiving the highest $\mathrm{N}$ rate regardless of $\mathrm{N}$ source. It was clear that to produce the highest yields, it was necessary to supply the secondary and micronutrients as well as the full recommended $\mathrm{N}$ rate.

Collards Spring 2013. The budgets for the 2013 collard crop followed the same trend as in the 2012 crop. This time, however, yields were reduced in all treatments. As a result, none of the treatments were profitable. The treatment with the smallest loss during the 2013 season was the HFF treatment with a loss of $\$ 1501 /$ ha followed by the INORGWM treatment with a loss of $\$ 3935 /$ ha and then the INORGWO with a loss of $\$ 4979 /$ ha (Table 7). Although all treatments performed below expectations, it was clear that the application of the full $\mathrm{N}$ rate and the addition of the secondary and micronutrients were critical to yield.

Summer squash 2013. The final crop in the rotation, summer squash, had reduced yield from the first crop in 2012. This was attributable in part to the intensive rotation that had preceded this crop as well as excessive rainfall. During this 2-month crop cycle, nearly 7 inches of rain was recorded at the research station (AWIS Weather Services Inc., 2013). Extended periods of rain can significantly increase $\mathrm{N}$ loss through denitrification, affecting both plant growth and yield (Mills and Jones, 1996). As a result of these factors, all treatments failed to be profitable. The overall loss was compounded by the additional cost allocated to this crop as a result of plastic removal as well as the need to apply additional fungicides to the crop. Additional fungicide applications were needed as a result of the increased disease pressure resulting from the cool, damp weather conditions that favored disease development. The treatment that lost the least amount was HFF with a loss of $\$ 347 /$ ha, following was INORGWM at a loss of $\$ 2008 / \mathrm{ha}$, and finally INORGWO at a loss of \$3343/ha (Table 7).
Overall, it was determined that the use of a HFF is a feasible option in vegetable production when using a plasticulture rotation. This is, however, true only when organic price premiums can be obtained. The cost to use the fertilizer was much higher than an inorganic $\mathrm{N}$ source such as urea $(\$ 24.68 / \mathrm{kg}$ $\mathrm{N}, \$ 1.11 / \mathrm{kg} \mathrm{N}$, respectively). The price per kilogram of $\mathrm{N}$ for the Schafer's Liquid Fish would be much higher than what was used for budgeting purposes if purchased in the small containers marketed to home gardeners. Therefore, the premium prices available in the organic food market are the key to profitability. It was also clear that to achieve acceptable yields, it was necessary to apply the HFF according the recommended $\mathrm{N}$ rates for each crop as outlined in the 2012 SE US Vegetable Crop Handbook (Kemble, 2012). Any reduction in applied N, whether it be in the organic or inorganic form, resulted in reduced yields.

Although this study focused on the use of $\mathrm{HFF}$ as the sole source of $\mathrm{N}$ in a cropping system, the results indicate that growers may benefit from using the HFF as an in-season supplement in an organic fertility system. The use of HFF as an injectable, quickly available $\mathrm{N}$ source provides organic growers with an additional fertility option when pre-plant nutrients have been depleted. Growers should research the crops that tend to obtain the highest price premiums and require the lowest $\mathrm{N}$ fertility and consider HFF as an economic option in organic production.

\section{Literature Cited}

AWIS Weather Services Inc. 2013. Daily weather observations for E.V. Smith. 27 Nov. 2013. $<$ http://www.awis.com/cgi-bin/uncgi/awondasta. uncgi $>$.

Beyond Pesticides. 2012. Organic food market continues to gain ground. 1 Nov. 2012. <http:// www.beyondpesticides.org/dailynewsblog/ $? \mathrm{p}=8289>$.

Bremner, J.M. and C.S. Mulvaney. 1986. Nitrogentotal. In: Page, A.L. (ed.) Methods of soil analysis, Part 2. Chemical and microbiological properties. 2nd Ed. Argon. Monogr. 9. ASA and SSSA, Madison, WI.

Camberato, J.J. 2001. Nitrogen in soil and fertilizers. SC Turfgrass Foundation News 8:6-10.

Chapin, L. 2012. Ag fields see organic growth. 27 Feb. 2013. <http://www.calstate.edu/pa/News/ 2012/Story/OrganicFarming.shtml>.

Gaskell, M. and R. Smith. 2007. Nitrogen sources for organic vegetable crops. HortTechnology $17: 431-441$.
Hartz, T.K. and P.R. Johnstone. 2006. Nitrogen availability from high-nitrogen containing organic fertilizers. HortTechnology 16:39-42.

Hartz, T.K., R. Smith, and M. Gaskell. 2010. Nitrogen availability from liquid organic sources. HortTechnology 20:169-172.

$\mathrm{He}$, Hongju. 1999. Study of growth adaptations and identification of glucosinolates on Chinese Brassicas. Herbert Utz Verlag GembH, Munchen, Germany.

Hewitt, T.D. 2003. North Florida research and education center enterprise vegetable budgets. Marianna, FL.

Jones, J.B., Jr.Plant nutrition manual. 1998. CRC Press, Boca Raton, FL.

Kemble, J.M. (ed.). 2012. Southeastern U.S. vegetable crop handbook. Vance Publishing Group, Lincolnshire, IL.

Lin, B.-H., T.A. Smith, and C.L. Huang. 2008. Organic premiums of US fresh produce. Renew. Agr. Food Syst. 23:208-216.

McEvoy, M. 2012. Sodium nitrate use in organic production. USDA, NOP (Notice 12-1), Washington, DC.

Mills, H.A. and J.B. Jones, Jr. 1996. Plant analysis handbook II. MicroMacro Publ. Inc., Athens, GA.

Rice, P.J., J.A. Hartman-Fetcho, A.M. Sadeghi, L.L. McConnell, C.B. Coffman, J.R. Teasdale, A. Abdul-Baki, J.L. Starr, G.W. McCarty, R.R. Herbert, and C.J. Hapeman. 2007. Reducing insecticide and fungicide loads in runoff from plastic mulch with vegetative-covered furrows. J. Agr. Food Chem. 55:1377-1384.

S.F. Organics. 2013. Frequently asked questions. 27 Feb. 2013. <http://www.sf-organics.com/ faq $/>$.

Sims, G.K., T.R. Ellisworth, and R.T. Mulvaney. 1995. Microscale determination of inorganic nitrogen in water and soil extracts. Commun. Soil Sci. Plant Anal. 26:303-316.

Tabatabai, M.A. (ed.). 1986. Sulfur in agriculture. 27th in series. American Society of Agronomy, Madison, WI.

U.S. Department of Agriculture. 1953. United States standards of collard greens or broccoli. Greens. U.S. Dept. Agr., Washington, DC.

U.S. Department of Agriculture. 1984. United States standards for grades of summer squash. Greens. U.S. Dept. Agr., Washington, DC.

U.S. Department of Agriculture. 2012. USDA releases results of the 2011 certified organic production survey. U.S. Dept. Agr., Washington, DC.

U.S. Department of Agriculture. 2013. Fruit and vegetable market news. 27 Nov. 2013. <http:// www.marketnews.usda.gov/portal/fv?paf_dm= full\&paf_gear_id $=1200002 \&$ startIndex $=1 \& \mathrm{dr}=$ $1 \&$ navType $=$ comm\&navClass $=$ VEGETABLES\& final $=$ true $>$.

Warncke, D.D. 2007. Nutrient management of cucurbits: Melon, pumpkin, cucumber, and squash. Indiana CCA Conference Proceedings. 